\title{
The clinical significance of anti-CCP antibodies in Korean JRA patients
}

\author{
Kwang Nam Kim ${ }^{1 *}$, Jung Woo Rhim² \\ From 21st European Pediatric Rheumatology (PReS) Congress \\ Belgrade, Serbia. 17-21 September 2014
}

\section{Introduction}

To determine the clinical significance of anti-CCP (anticitrullinated cyclic peptide) in Korean patients with JRA. Rheumatoid Factor (RF) is a non-specific serologic test in juvenile rheumatoid arthritis (JRA) but the anti-perinuclear autoantibodies are found in adult rheumatoid arthritis (RA) recently. One of these autoantibodies can detect epitopes called citrulline. The authors want to know that these autoantibodies can be applied in Korean JRA.

\section{Objectives}

The serum samples were obtained from 142 patients with arthralgia. The mean ages are 8.98 years old. The case group were 83 patients with JRA and the other control group were 59 patients with arthralgia who are not JRA.

\section{Methods}

The ant-CCP antibodies were assessed by an enzyme linked immunosorbent assay (ELISA) : INOVA Quant Lit CCP3 IgG ELISA test.

\section{Results}

The authors compared the anti-CCP values with each JRA subtypes. Each subtypes are systemic JRA (29 cases), pauci JRA (31 cases) and poly JRA (23 case). The p-values are 1.0, 0.272 and $<0.01$ respectively. We are also compared the anti-CCP values with RF-positive and RF-negative in poly JRA. The p-values are $<0.01$ and $<0.01$ both.

\section{Conclusion}

The authors compared the JRA group with the control group. The p-value revealed $<0.01$ significantly. We also compared each subtype of JRA with control group. Only the poly JRA group is significantly differences with

${ }^{1}$ Pediatrics, Hallym University Medical Center, An-Yang, Korea, Republic Of Full list of author information is available at the end of the article control group $(\mathrm{p}<0.01)$. We concluded that the test for anti-CCP in poly JRA patients are significantly benefit in the clinical field.

\section{Disclosure of interest}

None declared.

\section{Authors' details}

${ }^{1}$ Pediatrics, Hallym University Medical Center, An-Yang, Korea, Republic Of.

${ }^{2}$ Pediatrics, The Catholic Medical Center, Dae Jeon, Korea, Republic Of.

Published: 17 September 2014

doi:10.1186/1546-0096-12-S1-P198

Cite this article as: Kim and Rhim: The clinical significance of anti-CCP antibodies in Korean JRA patients. Pediatric Rheumatology 201412 (Suppl 1):P198
Submit your next manuscript to BioMed Central and take full advantage of:

- Convenient online submission

- Thorough peer review

- No space constraints or color figure charges

- Immediate publication on acceptance

- Inclusion in PubMed, CAS, Scopus and Google Scholar

- Research which is freely available for redistribution
C Biomed Central

(c) 2014 Kim and Rhim; licensee BioMed Central Ltd. This is an Open Access article distributed under the terms of the Creative Commons Attribution License (http://creativecommons.org/licenses/by/4.0), which permits unrestricted use, distribution, and reproduction in any medium, provided the original work is properly cited. The Creative Commons Public Domain Dedication waiver (http://creativecommons.org/publicdomain/zero/1.0/) applies to the data made available in this article, unless otherwise stated. 